\title{
LDHA wt Allele
}

National Cancer Institute

\section{Source}

National Cancer Institute. LDHA wt Allele. NCI Thesaurus. Code C106207.

Human LDHA wild-type allele is located in the vicinity of $11 \mathrm{p} 15.4$ and is approximately 14 $\mathrm{kb}$ in length. This allele, which encodes L-lactate dehydrogenase A chain protein, plays a role in fermentation. Mutation of the gene is associated with glycogen storage disease 11. 